\title{
The Changing World of Entrepreneurial Learning Resources
}

\author{
Daniel Forbes (University of Minnesota, Carlson School of Management)
}

KEYWORDS: Information, Software, Data, Social Media \& Networks, Entrepreneurship, Information Technology.

Steve Jobs died in October 2011. Since then, much has been written about Jobs' life and the legacies he left through his company, Apple, and through his impact on technology more generally (e.g., Isaacson, 2011). Today l'd like to reflect on a broader "ripple effect" of Jobs' legacy: the emergence of a worldwide infrastructure of entrepreneurial learning, which is giving many more would-be entrepreneurs the tools they need to succeed.

\section{Learning Infrastructures}

By "infrastructure," I mean an evolving bundle of resources - including books, blogs and online communities, among other things - that help people learn about whether, when and how to start a new business. Such resources are common today, and they are expanding rapidly.

But I don't think we have a clear understanding of what these resources are, how they work, and what they mean for the future of entrepreneurship. Recently, that belief prompted me to write a book chapter, in which I call attention to these learning resources and encourage people to talk about them and study them in more detail (Forbes, 2014). The chapter appears in the "Handbook of Entrepreneurial Cognition," published in 2014 by Edward Elgar Publishers, and you can link to a copy of it here

(https://carlsonschool.umn.edu/sites/carlsonschool.umn. edu/files/2021-09/forbes_hec_chapter_acc_draft.pdf).I summarize below some of the key points I make in that chapter.

The Oxford Dictionaries define infrastructure as the "structures and facilities needed for the operation of a society or an enterprise." When we think about the infrastructure of a society, we often think of roads or sewer systems. But a society's infrastructure can include less tangible things, too.

\section{Tangibles and Intangibles}

For example, as a number of scholars have pointed out, the entrepreneurial activity in a society at any given time depends on both the tangible and intangible elements of that society's infrastructure, including those that affect the extent to which people have the knowledge and skills needed to be innovative (e.g., Feldman \& Florida, 1994; Van de Ven, 1993). When I refer to an infrastructure of entrepreneurial learning, therefore, I have in mind resources like these:

1. Books and periodicals. Today, people can access books and periodicals written by people who have been entrepreneurs, investors and advisors to new ventures of all kinds. Through such publications, people stand to learn from the collective experience of others who have lived through several "generations" of entrepreneurial activity, including the personal computing revolution of the 1980s and Internet boom of the late 1990s.

2. Informal learning communities. Today, people of all ages can participate in informal groups that share knowledge about various aspects of the new venture creation process. These networks leverage in-person mechanisms of knowledge exchange, as in the case of the Meetup networks that assemble in cities around the world, as well as virtual mechanisms, such as Internet blogs and Twitter feeds devoted to various aspects of entrepreneurship. Often, too, these communities are tailored to the needs of specific categories of people (e.g., military veterans or mothers with young children) or specific businesses (e.g., food trucks or "app" businesses).

3. Formal educational programs. Today, students in college and MBA programs across the globe can take courses - and even whole programs of study - related to entrepreneurship 
(e.g., Morris et al., 2012). Students in these programs learn through conventional business education methods, such as those based on books, theories and cases, as well as through "experiential learning" initiatives that help them learn while launching, managing and assisting real businesses.

4. Research conversations. Today, scholars based in universities and elsewhere study issues like new venture strategy, venture capital and innovation policy with the same range of approaches and tools used to study other important parts of our social world (Aldrich, 2012). For example, the Global

Entrepreneurship Monitor documents startup activity in various countries, and the Kauffman Foundation supports and disseminates other research on entrepreneurial topics.

\section{Easy to Take for Granted}

Resources like these are in such abundance today that it is easy to lose track of how quickly they've evolved. But few such resources existed when Apple Computer was founded in 1976. These resources continue to evolve, too, and they interact in some fascinating ways.

For example, imagine a middle manager in an established firm who goes to iTunes to download podcasts of panel discussions about startup formation. The panel discussions might have taken place during an event hosted by a formal educational institution, such as Stanford. But our manager can listen to those podcasts in the car during her daily commute (to a job she is itching to leave, perhaps). And then she can share or critique the lessons contained in the podcast via social media later that evening, thereby feeding knowledge back to the infrastructure for future participants.

\section{Giving Jobs his Due}

Clearly, this infrastructure of entrepreneurial learning isn't attributable to Jobs alone. In fact, if we ask "who built it?," the answer is complex. Ultimately, this infrastructure was built through the creative collaboration of many individuals, groups, firms and institutions around the world over the course of decades (Johnson, 2012).

But Jobs gave that infrastructure a big push forward in several ways: through the example he set as an individual entrepreneur, through the iconic company that was his master work, and through the technologies he and his cohort of fellow entrepreneurs set in motion. The three years that have passed since his death have given us time to reflect and take stock of that infrastructure and consider what it means for our future.

As we think about what it means, it's important to remember that historically, knowledge about entrepreneurship moved pretty slowly in society. Generally, a person had to know entrepreneurs personally in order to learn what those people had to teach. And whether you knew an entrepreneur was often limited by things you couldn't control - like which household you were born into, or which social networks you had access to. The infrastructure of entrepreneurial learning breaks down some of those barriers and makes it possible for entrepreneurial knowledge to be shared much faster and with a wider range of people.

If the infrastructure is well-maintained by its many participants, it can significantly improve the quantity and quality of the innovations our societies generate. Clearly, many new ventures will continue to fail; that risk will always be an inherent part of the entrepreneurial process. But societies as a whole can win if an infrastructure exists to help people make entrepreneurial decisions - decisions about whether, when and how to launch their businesses - as effectively as possible.

\section{Going Forward: Investing in Access}

For the constructive potential of the infrastructure to be realized, two key challenges need to be met.

First, we need to keep investing in the infrastructure to improve the quality of each part of it. For example, we need to make the knowledge that's created and exchanged more accurate and more useful over time.

Second, we need to broaden access to the infrastructure so that the knowledge it offers is available to wider circles of people in our society, including people who might face barriers to accessing and interpreting the knowledge it has to offer. In facing these challenges, we can learn from the example of an individual entrepreneur who was passionately committed to continuous improvement and ensuring broad, userfriendly access: Steve Jobs.

\section{References}

Aldrich, H. 2012. The emergence of entrepreneurship as an academic field. A personal essay on institutional 
entrepreneurship. Research Policy, 41: 1240-1248.

Feldman, M. \& Florida, R. 1994. The geographic sources of innovation: Technological infrastructure and product innovation in the United States. Annals of the American Association of Geographers, 84: 210-229.

Forbes, D. 2014. "The infrastructure of entrepreneurial learning." In J.R. Mitchell, R.K. Mitchell \& B. RandolphSeng (Eds.), Handbook of Entrepreneurial Cognition, pp. 364-382. Cheltenham, UK: Edward Elgar.

Isaacson, W. 2011. Steve Jobs. Simon \& Schuster.

Johnson, S. 2012. "The Internet? We built that." New York Times. September 21.

Morris, M., Kuratko, D. \& Cornwall, J. 2012. Entrepreneurship programs and the modern university. Edward Elgar Publishing.

Van de Ven, A. 1993. The development of an infrastructure for entrepreneurship. Journal of Business Venturing, 8: 211-230.

Additional Search Terms: online resources for entrepreneurs, researching entrepreneurship, learning about entrepreneurship 